\title{
RESPONSE OF PEACE LILY (SPATHIPHYLLUM WALLISII REGEL) PLANTS TO FOLIAR SPRAY WITH SOME GROWTH REGULATORS AND MICROELEMENTS
}

\author{
Naglaa F.S. Elbohy \\ Ornamental Plants and Landscape Gardening Res. Dept., Hort. Res. Inst., ARC, Giza, Egypt.
}

ABSTRACT: A pot experiment was conducted during two successive seasons (2016/2017 and 2017/2018) at the greenhouse of the Ornamental Dept., El-Kassasin Res. Station, Ismailia Governorate, Egypt. This study was carried out to investigate the effect of foliar spraying with some growth regulators (gibberellic acid $\left(\mathrm{GA}_{3}\right)$ at 100 and 200 ppm, kinetin (Kin) at 100 and 200 ppm beside the control treatment) and a microelements mixture at $(0,1,2$ and $3 \mathrm{~g} / \mathrm{l})$ on

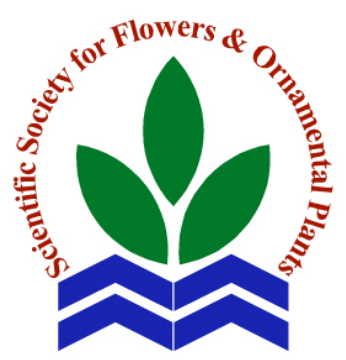

Scientific J. Flowers \& Ornamental Plants, 5(4):275-291 (2018).

Received:

$12 / 12 / 2018$

Accepted:

23/12/2018 vegetative growth, root system and quality of peace lily (Spathiphyllum wallisii Regel) plant. Results showed that the interaction treatment between spraying peace lily plants with Kin at $100 \mathrm{ppm}$ in addition to the microelements mixture at $2 \mathrm{~g} / \mathrm{l}$ gave the highest values regarding number of leaves/plant, stem diameter and leaf area, number of roots/plant in both seasons, fresh weight of roots in the $2^{\text {nd }}$ season and dry weight of root, fresh and dry weight of shoots, number of both shoots and flowers/plant in both seasons. The interaction treatment between spraying plants with $\mathrm{GA}_{3}$ at $200 \mathrm{ppm}$ and $2 \mathrm{~g} / \mathrm{l}$ microelements mixture gave the tallest plants in both seasons. However, the interaction treatment between Kin at $100 \mathrm{ppm}$ and spraying plants with $3 \mathrm{~g} / \mathrm{l}$ microelements mixture was the best interaction treatment for enhancing the concentration of total chlorophyll and total carbohydrates in shoots, in both seasons. Generally, the best interaction treatments for increasing growth, flowering and biochemical constituents was obtained with Kin at 100 ppm and $2 \mathrm{~g} / \mathrm{l}$ microelements.

Key words: Spathiphyllum wallisii, gibberellic acid, kinetin, microelements mixture, vegetative growth, chemical composition.

\section{INTRODUCTION}

Peace lily (Spathiphyllum wallisii Regel) is a member of the family Araceae and one of the most popular indoor houseplants (Sardoei 2014a). Interest in peace lily is steadily increasing as it is a shade tolerant indoor plant, easy-care, with dark green foliage and white spathes. The showy white spathes of Spathiphyllum enhance its popularity and market niche as a flowering foliage plant (Henny et al., 2004). Although it was initially a plant for containers, in recent years, the culture of this plant has been greatly expanded to the production of cut flowers

Gibberellins form a large family of diterpenoid compounds, some of which are bioactive growth regulators that control such diverse developmental processes as seed germination, stem elongation, leaf expansion, trichome development, in addition to flower and fruit development (Davies, 1995). Moreover, $\mathrm{GA}_{3}$ application 
increased petiole length, leaf area and delayed petal abscission and color fading (senescence) by the hydrolysis of starch and sucrose into fructose and glucose (Khan and Chaudhry, 2006).

Kinetin, the most synthetic known cytokinin, has a furfuryl ring at the N6position of adenine and was identified in both animal cellular DNA and plant tissue extracts. Kinetin is known to be essential to plants and is a necessary growth regulator for these organisms. Although its role for animals is well known, in the case of plants, it needs further investigation. Kinetin in low concentrations influences plants in a positive way but higher concentrations are toxic (Barciszewski et al., 2000).

Spraying plants with either kinetin or $\mathrm{GA}_{3}$ gave the best vegetative growth, both fresh and dry weight of foliage, chemical contents and total chlorophyll than unsprayed plants. In this respect, similar results were obtained elsewhere by Youssef and Ismaeil (2009) on Clivia miniata, Ibrahim et al. (2010) on croton, Mohammadipour (2012) on peace lily, Youssef and Mady (2013) on Aspidistra elatior, Rahbarian et al. (2014) on peace lily, Sardoei (2014 b) on Ficus benjamina, Schefflera arboricola and Dizigotheeca, Youssef, and Abd El-Aal (2014) on Hippeastrum vittatum, Mohamed (2017) on aster and by Abou-El-Ghait et al. (2018) on Chrysanthemum.

Micronutrients play vital roles in the growth and development of plants, due to their stimulatory and catalytic effects on metabolic processes and ultimately on flower yield (Lahijie, 2012). The role of zinc and iron in crop nutrition is well recognized as they are used for bio-synthesis of plant auxins, nitrogen metabolism, and for oxidation-reduction reactions, which are considered to be necessary for plant growth and development. They are also involved in chlorophyll formation, photosynthesis, important enzyme system and respiration in plants. Boron also plays a very important role in vital functions of the plant, including meristem, sugar and hydrocarbon metabolism and their transfer, RNA and cytokinin production and transfer, pollen building and seed formation, (Murthy et al., 2006). Zinc is necessary to activate many enzymes, enzymes that are activated by the zinc are Tryptophan synthetase superoxide dismutase and dehydrogenases. Lack of zinc causes deficiency in formation of RNA and protein. Therefore, the plant with lack of zinc is poor in amount of protein (Praveena et al., 2018).

Manganese is regarded as an activator of many different enzymatic reactions and takes part in photosynthesis. (Sajedi et al., 2009).

Many researchers found that spraying floricultural plants with microelements gave the best results for growth and biochemical constituents in plant than untreated plants like what has been reported by Wahba and Ezz EL-Din (2002) on Chrysanthemum; Dashora et al. (2004) on marigold; Ahmad et al. (2010) on rose; Khalifa et al. (2011) on Iris; Khosa et al. (2011) on Gerbera; Amuamuha et al. (2012) on marigold; Mohammadipour (2012) on peace lily; Amran (2013) on Pelargonium graveolens; Bashir et al. (2013) on gerbera; Fahad et al. (2014) and Chopde et al. (2015) on Gladiolus; Soni and Godara (2015) and by Pal et al. (2016) on gerbera.

Thus, the aim of this work was to investigate the effect of foliar application with some growth regulators (gibberellic acid, and kinetin) and microelements on vegetative growth, root system and quality of Peace lily (Spathiphyllum wallisii Regel) plant.

\section{MATERIALS AND METHODS}

The present experiment was conducted during two successive seasons (2016/2017 and 2017/2018) at the greenhouse of the Ornamental Dept., El Kassasin Research Station, Ismailia Governorate, Egypt. This study was designed to investigate the effect of foliar application with some growth regulators (gibberellic acid, and kinetin) and microelements on vegetative growth, root 
system and quality of peace lily (Spathiphyllum wallisii Regel) plant.

\section{Experimental procedure and treatments:}

The Spathiphyllum plugs (small plants of 8-10 cm long) used in this study were obtained from Pico Modern Agric., private company. On $20^{\text {th }}$ April, 2016, the plants were individually transplanted in $20-\mathrm{cm}$ diameter plastic pots filled with a mixture of peatmoss + perlite + sand, at the ratio of 1:1:1 (v/v/v) and held under greenhouse conditions. After 30 days from transplanting, the plants were sprayed every 4 weeks (from 20 May till 20 August), with the following concentrations of growth regulators treatments gibberellic acid at 100 and 200 ppm, kinetin at 100 and 200 ppm beside, the control treatment, and microelements at 0,1 , 2 and $3 \mathrm{~g} / \mathrm{l}$. The plants were sprayed by a hand sprayer until run off point.

\section{Experimental design:}

The treatments were arranged in a factorial experiment in complete randomized design with three replicates (each replicate contained 6 pots). The first factor was growth regulators, while the second one was foliar spraying with microelement treatments. So, this study included 20 treatments (including the control).

Gibberellic acid and kinetin were obtained from El-Gomhouria Co. for trading medicines, chemicals and medical appliances, Sharkia Governorate, Zagazig, Egypt, while the source of the microelements mixture was the commercial product Micronate 15, which contains iron at $4 \%$, zinc at $4 \%$, manganese at $3 \%$, magnesium at $1 \%$ and cupper at $0.5 \%$ and was produced by Al-Qawafel Ind. Agr. Co., Jordan.

\section{Data recorded:}

\section{Growth characters:}

A sample of six plants from every treatment was taken at $15^{\text {th }}$ of September to investigate the following growth parameters: plant height $(\mathrm{cm})$, stem diameter $(\mathrm{cm})$, number of leaves/plant, leaf area $\left(\mathrm{cm}^{2}\right)$, fresh and dry weights of leaves (g/plant), number of roots/plant, root length $(\mathrm{cm})$ for the longest root, fresh and dry weights of roots/plant (g), number of shoots/root, number of flowers and shoots/plant, total chlorophylls and total carbohydrates.

\section{Root system traits:}

The roots of peace lily (Spathiphyllum wallisii Regel) plants were carefully separated by washing then placed in a flat glass dish containing a little amount of water. Roots were straightened with forceps, to hold them in position, according to Helal and Sauerbesk (1986), and the following data were recorded: root length $(\mathrm{cm})$, fresh and dry weights of roots (g), and number of roots per plant.

\section{Chemical constituents:}

Determination of total chlorophyll (SPAD) in fresh leaves was carried out according to A.O.A.C. (1980). Total carbohydrates percentage in dry leaves was determined colorimetrically using the method described by Dubois et al. (1956).

\section{Statistical analysis:}

Data recorded on both vegetative growth and chemical composition were statistically analyzed. An analysis of variance (ANOVA) was carried out, and the means of the recorded data were compared using the least significant difference (L.S.D.) test at the 5\% level, as described by Snedecor and Cochran (1980).

\section{RESULTS AND DISCUSSION}

\section{Vegetative growth:}

\section{Effect of growth regulators:}

Results presented in Table (1) show the effect of growth regulators on the vegetative growth in both seasons. Spraying peace lily with different growth regulators such as gibberellic $\left(\mathrm{GA}_{3}\right)$ or kinetin (Kin) at different rates resulted in a significant effect on plant height, number of leaves/plant, stem diameter and leaf area than in unsprayed plants in both seasons. 
Naglaa F.S. Elbohy

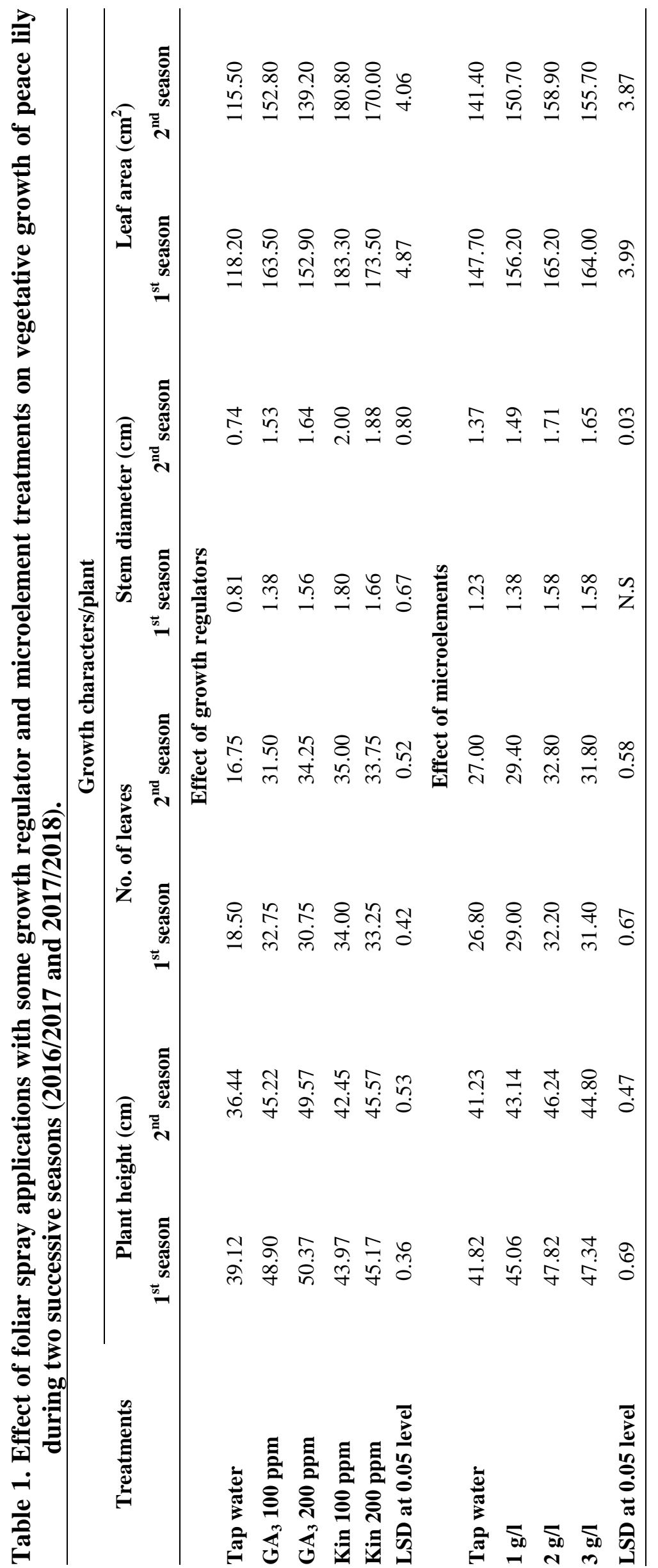


Spraying plants with $\mathrm{GA}_{3}$ at $200 \mathrm{ppm}$ gave the tallest plants in both seasons, while spraying plants with Kin at $100 \mathrm{ppm}$ gave the highest values of number of leaves/plant, stem diameter and leaf area in both seasons.

The relative increases in leaf area were about 55.07 and $56.53 \%$ for the plants which were sprayed with Kin at $100 \mathrm{ppm}$, followed by 46.78 and $47.18 \%$ for Kin at $200 \mathrm{ppm}$ over unsprayed plants in the $1^{\text {st }}$ and $2^{\text {nd }}$ seasons, respectively.

These results agree with those reported by Mohammadipour (2012) on peace lily and Ibrahim et al. (2010) on croton plants.

\section{Effect of microelements:}

Spraying peace lily plants with a microelements mixture at different rates had a significant effect on plant height, number of leaves/plant, stem diameter and leaf area than in unsprayed plants in both seasons, except for stem diameter in the $1^{\text {st }}$ season (Table, 1). However, the highest values of plant height, number of leaves/plant, stem diameter and leaf area were obtained with the plants sprayed with $2 \mathrm{~g} / \mathrm{l}$ microelements, followed by the plants which were sprayed with $3 \mathrm{~g} / \mathrm{l}$ in both seasons.

The relative increases in leaf area were 11.84 and $12.37 \%$ for the plants which were sprayed with $2 \mathrm{~g} / \mathrm{l}$ microelements, followed by 11.03 and $10.11 \%$ for $3 \mathrm{~g} / \mathrm{l}$ microelements over unsprayed plants in the $1^{\text {st }}$ and $2^{\text {nd }}$ seasons, respectively.

This increase in vegetative growth characters of peace lily as a result of application of microelements ( that contain Zn) might be explained by synthesis of tryptophan, a precursor of indole acetic acid (auxin) which is accelerated by zinc and as such helps the plant to maintain apical dominance, polarity and growth. This is in conformity with other similar observations made by Misra (2001) on chrysanthemum, Khosa et al. (2011) and Bashir et al. (2013) on gerbera and Fahad et al. (2014) on gladiolus.

\section{Effect of the interaction between growth regulators and microelements:}

Results presented in Table (2) show that the interaction between growth regulators and microelements had significant effects on all vegetative growth parameters of peace lily in both seasons, except that of stem diameter in the $1^{\text {st }}$ season.

The interaction between sprayed plants with $\mathrm{GA}_{3}$ at $200 \mathrm{ppm}$ and $2 \mathrm{~g} / \mathrm{l}$ microelements gave the tallest plants in both seasons. While the interaction between sprayed plants with Kin at 100 ppm and 2 g/l microelements gave the highest values of number of leaves/plant, and leaf area in both seasons.

The relative increases in leaf area were about 80.73 and $83.67 \%$ for the interaction between Kin at $100 \mathrm{ppm}$ and $2 \mathrm{~g} / \mathrm{l}$ microelements, followed by 79.13 and $74.39 \%$ for the interaction between Kin at $100 \mathrm{ppm}$ and $3 \mathrm{~g} / \mathrm{l}$ microelements over unsprayed plants in the $1^{\text {st }}$ and $2^{\text {nd }}$ seasons, respectively.

\section{Root system/plant:}

\section{Effect of growth regulators:}

Results presented in Table (3) show that both growth regulators at different rates had significant effects on number of roots/plant, root length, both fresh and dry weights/root than in unsprayed peace lily plants in both seasons.

Number of roots/plant, root length, both fresh and dry weights/plant were at the highest values when plants were treated with Kin than plants treated with $\mathrm{GA}_{3}$ in both seasons. However, spraying peace lily plants with Kin at $100 \mathrm{ppm}$ gave the highest values in this respect in both seasons.

The relative increases in dry weight of roots/plant were 66.20 and $54.48 \%$ for the plants sprayed with Kin at $100 \mathrm{ppm}$, and 63.31 and $64.88 \%$ for Kin at 200 ppm over unsprayed plants in the $1^{\text {st }}$ and $2^{\text {nd }}$ seasons, respectively. 
Naglaa F.S. Elbohy

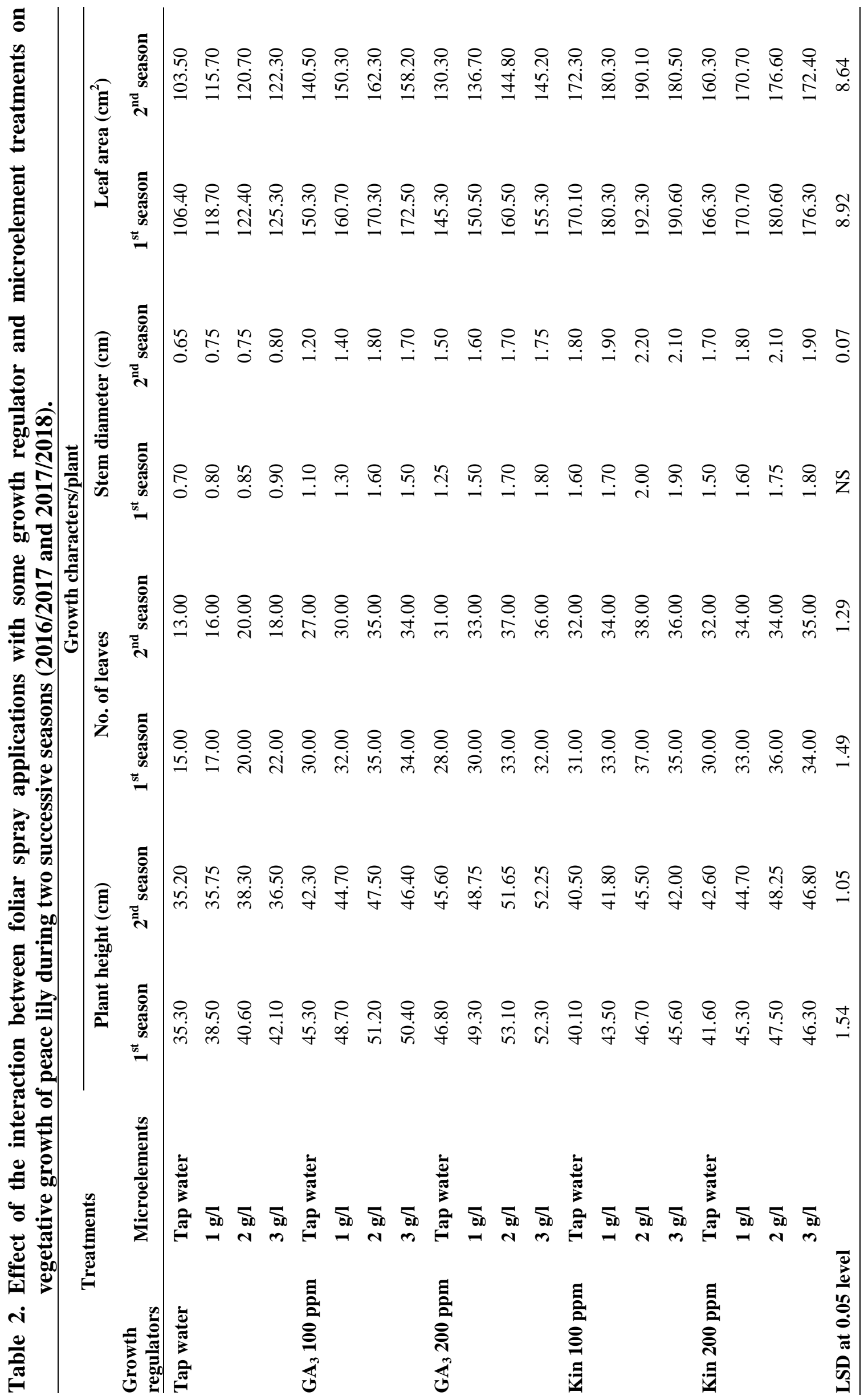


Scientific J. Flowers \& Ornamental Plants, 5(4):275-291 (2018)

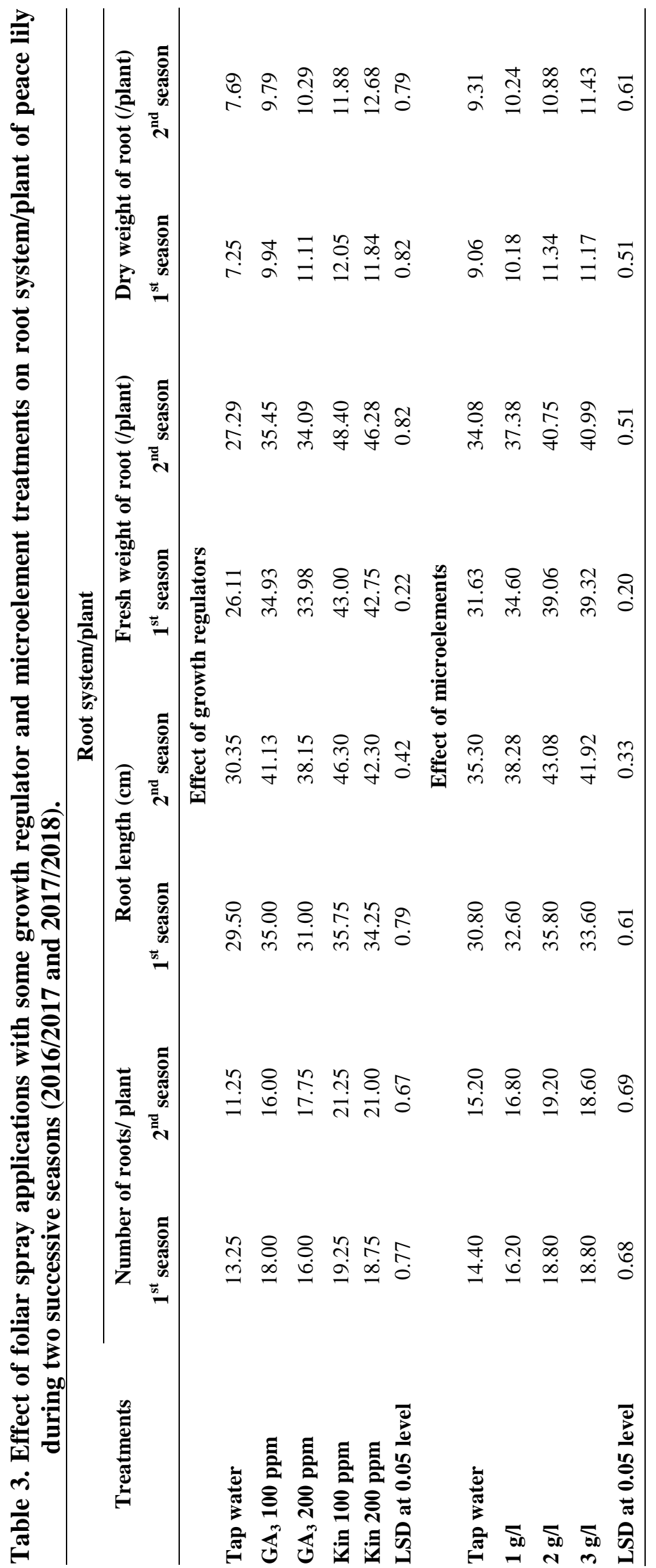


These results are in agreement with those reported by Sardoei (2014a) on Ficus benjamina, Schefflera arboricola and Dizigotheeca elegantissima.

\section{Effect of microelements:}

Number of roots/plant, root length, both fresh and dry weights/plant of peace lily have been affected by microelements as foliar spray than in unsprayed plants in both seasons (Table, 3).

Spraying plants with $2 \mathrm{~g} / \mathrm{l}$ significantly increased number of roots/plant, root length, both fresh and dry weights/plant with nonsignificant differences with $3 \mathrm{~g} / \mathrm{l}$ in most cases in both seasons.

The obtained results here were alike those reported by Mohammadipour (2012) on Aglaonema, Dieffenbachia, Spathiphyllum, Epipremnum, and Syngonium.

\section{Effect of the interaction between growth regulators and microelements:}

The interaction between growth regulators and microelements had significant effect on root system/plant than unsprayed plants in both seasons (Table, 4).

The interaction between spraying plant with Kin at $100 \mathrm{ppm}$ and microelements at 2 $\mathrm{g} / \mathrm{l}$ gave the highest values of number of roots/plant in both seasons, fresh weight of roots in the $2^{\text {nd }}$ season and dry weight of roots in the $1^{\text {st }}$ season, while the interaction between $100 \mathrm{ppm}$ Kin and $3 \mathrm{~g} / \mathrm{l}$ microelements gave the highest values of root length in the $2^{\text {nd }}$ season and fresh weight of roots in the $1^{\text {st }}$ season. The interaction between Kin at 200 ppm and microelements at $3 \mathrm{~g} / \mathrm{l}$ gave the highest values of dry weight of roots in the $2^{\text {nd }}$ season.

The relative increases in dry weight of roots/plant were about 113.07 and $91.16 \%$ for the interaction between Kin at $100 \mathrm{ppm}$ and $2 \mathrm{~g} / \mathrm{l}$ microelements and 107.69 and $118.60 \%$ for the interaction between Kin at $200 \mathrm{ppm}$ and $3 \mathrm{~g} / \mathrm{l}$ microelements over unsprayed plants in the $1^{\text {st }}$ and $2^{\text {nd }}$ seasons, respectively.

\section{Shoot and flowering characteristics:}

\section{Effect of growth regulators:}

Results presented in Table (5) show that spraying peace lily plants by both $\mathrm{GA}_{3}$ and Kin at different concentrations had significant effects on both fresh and dry weights of shoot, number of both shoots and flowers/plant than in unsprayed plants in both seasons.

The best treatment for increasing fresh and dry weight of shoot and number of shoots/plant was obtained with the plants sprayed with Kin at $100 \mathrm{ppm}$ in both seasons, with no significant differences at the same time with Kin at $200 \mathrm{ppm}$ for fresh weight of shoot and with either Kin or $\mathrm{GA}_{3}$ at $200 \mathrm{ppm}$ regarding dry weight of shoot in the $1^{\text {st }}$ season.

Concerning number of flowers/plant, the same result data show that, in general, all sprayed treatments recorded increases in number of flowers/plant more than in unsprayed plants in both seasons. However, $\mathrm{GA}_{3}$ at $200 \mathrm{ppm}$ was effective in a better manner in this concern.

The relative increases in fresh weight of shoot/plant were 41.22 and $42.74 \%$, for plants sprayed with Kin at $100 \mathrm{ppm}$, and 39.92 and $33.73 \%$ for Kin at 200 ppm over unsprayed plants in the $1^{\text {st }}$ and $2^{\text {nd }}$ seasons, respectively.

The increases in number of flowers/plant were about 116.66 and $160 \%$ for the plants sprayed with $\mathrm{GA}_{3}$ at $200 \mathrm{ppm}$ over unsprayed plants in the $1^{\text {st }}$ and $2^{\text {nd }}$ seasons, respectively.

The obtained results might be due to the role of kinetin on promoting protein synthesis, increasing cell division and enlargement (Cheema and Sharma, 1982). Moreover, these results might be explained by the role of kinetin in promoting proteins, soluble and non-soluble sugars synthesis, or may be due to the ability of kinetin for making the treated area to act as a sink in which nutrients from other parts of the plant are drawn (Salisbury and Ross, 1974). 
Scientific J. Flowers \& Ornamental Plants, 5(4):275-291 (2018)

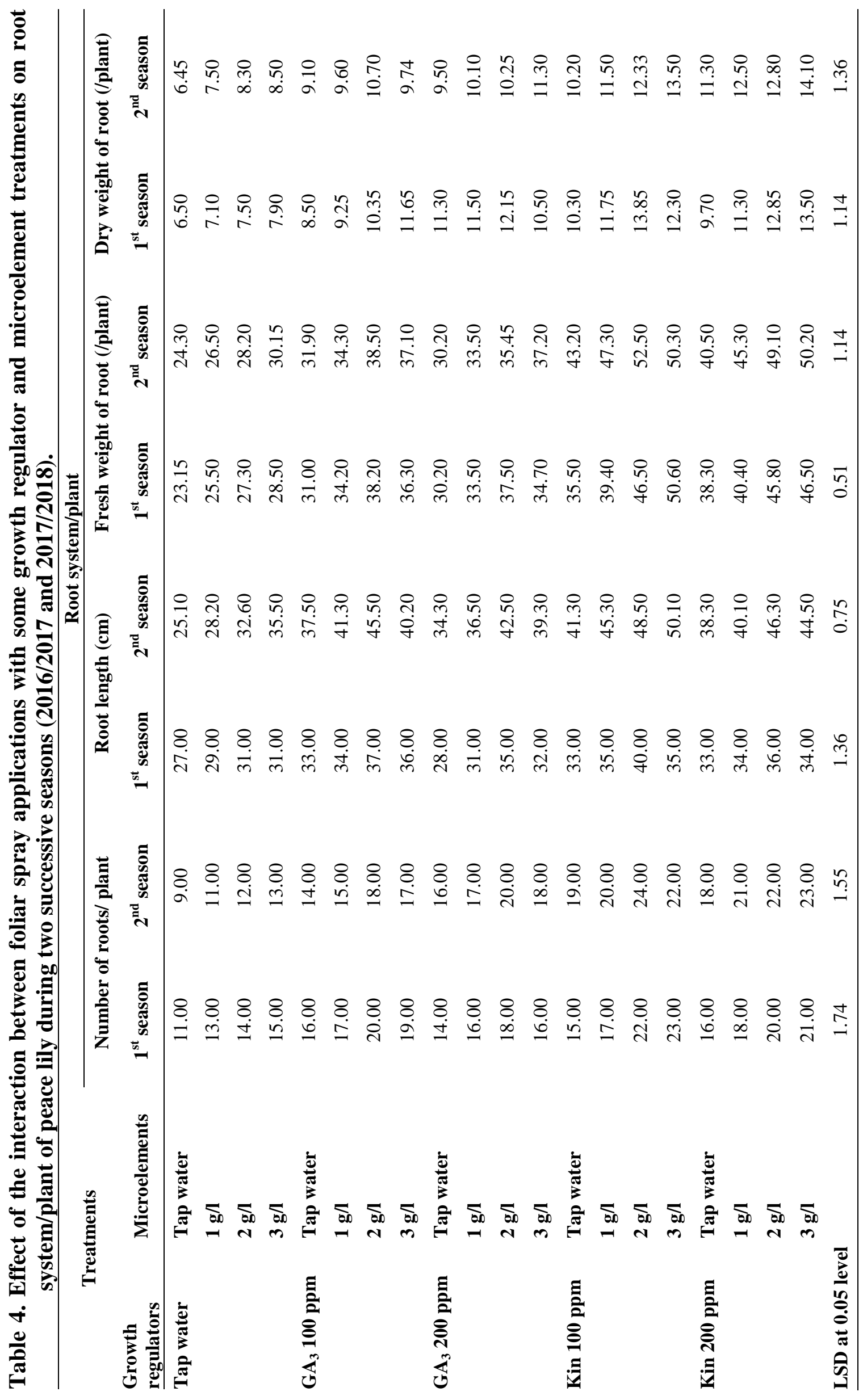


Naglaa F.S. Elbohy

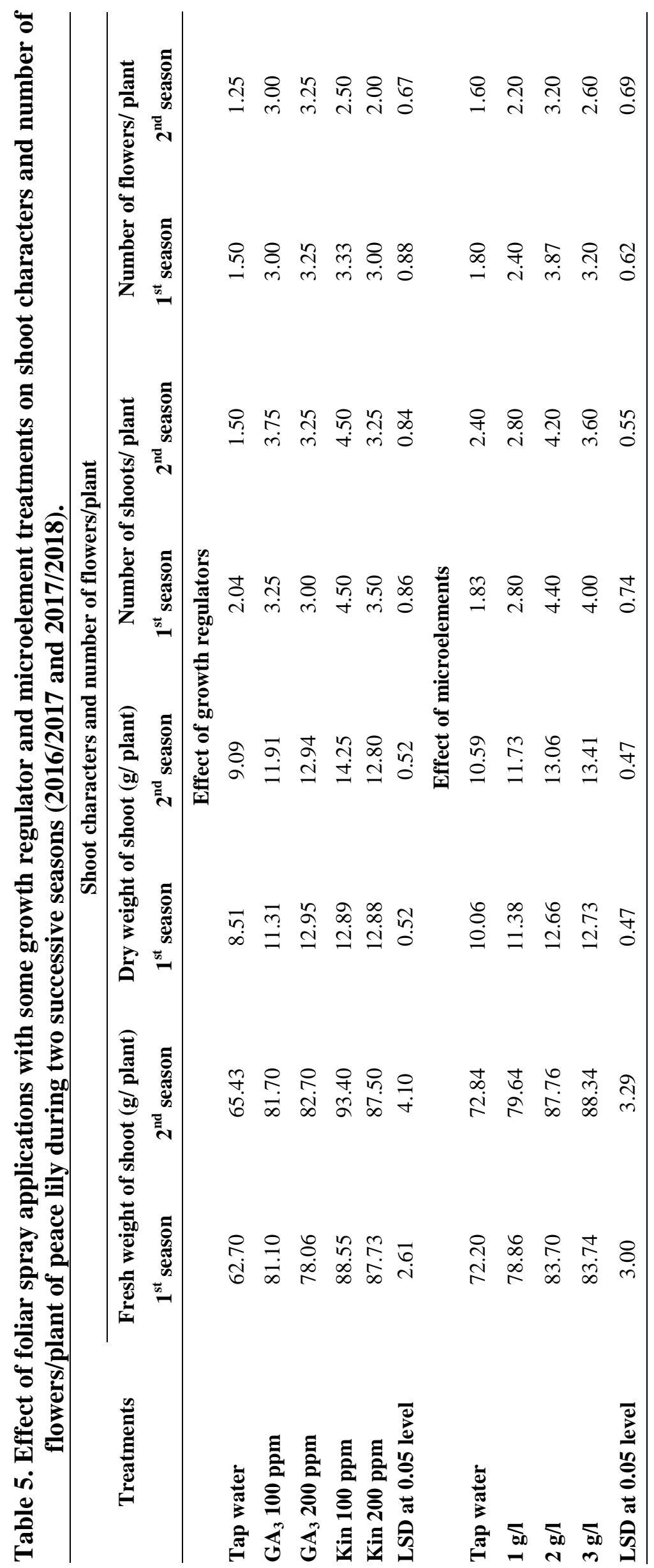


The results are in conformity with those reported by El-Malt et al. (2006), Youssef, and Abd El-Aal (2014) on Hippeastrum vittatum, Mohamed (2017) on aster and Abou-El-Ghait et al. (2018) on Chrysanthemum.

\section{Effect of microelements:}

Foliar sprayed microelements had significant effects on both fresh and dry weights of shoot, number of shoots and flowers/plant more than in unsprayed plants in both seasons (Table, 5).

Spraying peace lily plants with microelements at $2 \mathrm{~g} / \mathrm{l}$ significantly increased fresh and dry weight of shoots, both number of shoots and flowers/plant in both seasons, with no significant differences with $3 \mathrm{~g} / \mathrm{l}$ microelements for fresh and dry weight of shoot/plant in both seasons and both number of shoots and flowers/plant in the $1^{\text {st }}$ season.

The relative increases in fresh weight of shoot/plant were 15.92 and $20.48 \%$ and in number of flowers/plant were about 115 and $100 \%$ over unsprayed plants in $1^{\text {st }}$ and $2^{\text {nd }}$ seasons, respectively.

These results are in harmony with those stated by Bashir et al. (2013), Soni et al. (2015) and Pal et al. (2016) on gerbera, Fahad et al. (2014) and Chopde et al. (2015) on Gladiolus.

\section{Effect of the interaction between growth regulators and microelements:}

The interaction between growth regulators and microelements exhibited positive effects on fresh and dry weight of shoots, number of both shoots and flowers/plant than in unsprayed plants in both seasons (Table, 6).

The maximum values of fresh and dry weight of shoots, number of both shoots and flowers/plant were obtained with the interaction between spraying with Kin at 100 ppm and $2 \mathrm{~g} / \mathrm{l}$ microelements in both seasons.
The relative increases in fresh weight of shoot/plant were 70.93 and $63.90 \%$ for the interaction between Kin at 100 ppm and 2 g/l microelements and 68.73 and $53.49 \%$ for the interaction between Kin at 200 ppm and $3 \mathrm{~g} / \mathrm{l}$ over unsprayed plants in the $1^{\text {st }}$ and $2^{\text {nd }}$ seasons, respectively.

\section{Chemical composition:}

\section{Effect of growth regulators:}

Results presented in Table (7) show that there were significant differences between both growth regulators at the different concentrations and unsprayed plants concerning total chlorophylls and total carbohydrates in leaves of peace lily in both seasons.

Spraying plants with Kin at 100 ppm had significant effects on total chlorophyll and total carbohydrates in leaves with no significant differences between Kin at 200 ppm for total chlorophyll in both seasons and total carbohydrates in the $1^{\text {st }}$ season.

The increases in total chlorophyll in shoots were 27.5 and $63.29 \%$, total carbohydrates were 13.68 and $17.60 \%$ for the plants sprayed with Kin at $100 \mathrm{ppm}$, and 32.91 and $63.82 \%$ for total chlorophyll and 11.64 and $12.61 \%$ for total carbohydrates with plants sprayed with Kin at 200 ppm over unsprayed plants in the $1^{\text {st }}$ and $2^{\text {nd }}$ seasons, respectively.

As for the explanation of the incremental effect of kinetin on chemical constituents of peace lily content, it could be interpreted here by the fact that kinetin treatments stimulated the endogenous cytokinins synthesis. Also, there is an intimate relationship between cytokinins and chlorophylls metabolism in both excised or detached leaf disks and intact plants,i.e. cytokinins retard chlorophylls degradation, preserve it and increase its synthesis (Devlin and Witham, 1983).

Results in this research study agree with those of Youssef, and Abd El-Aal (2014) on 
Naglaa F.S. Elbohy

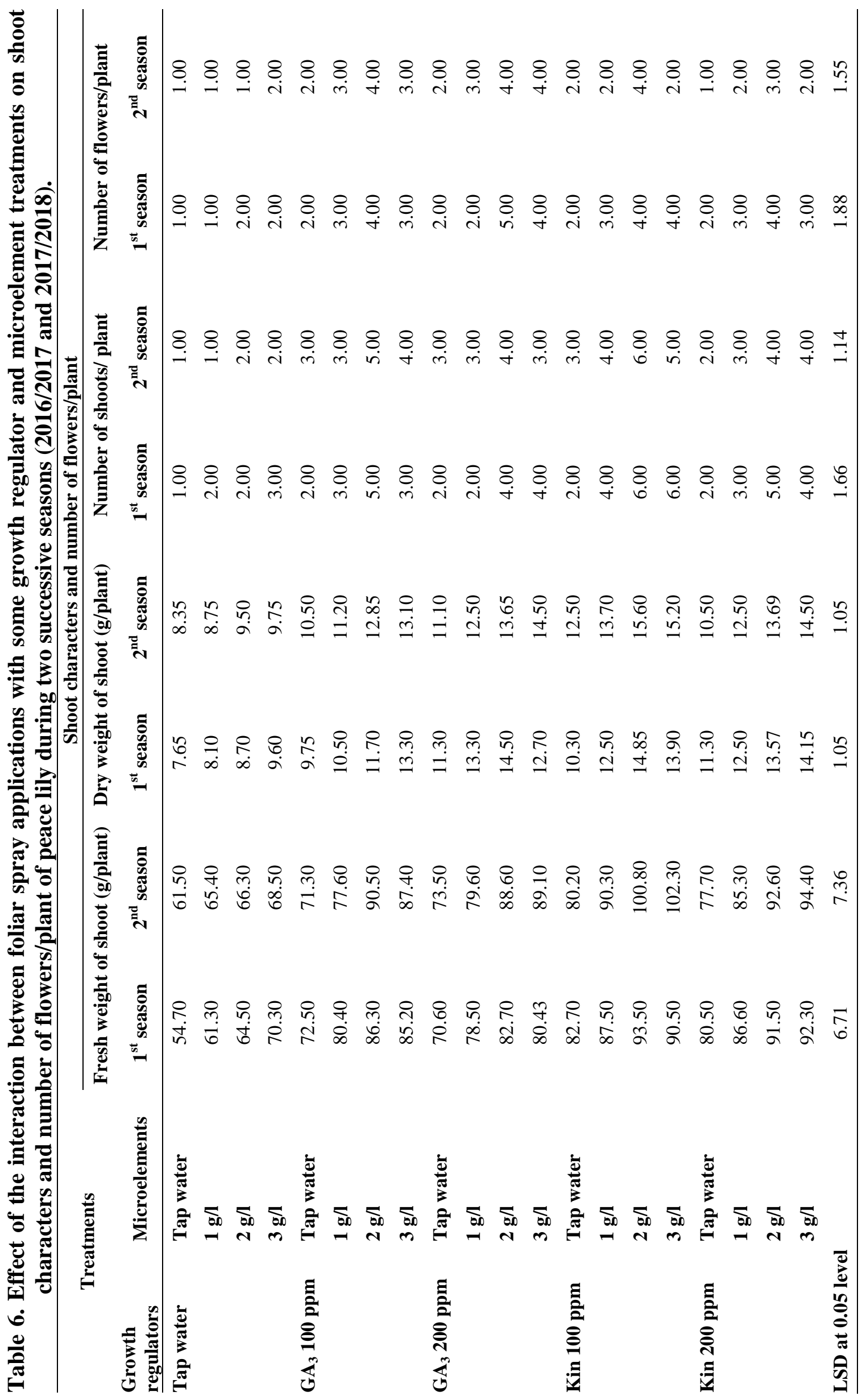


Table 7. Effect of foliar spray applications with some growth regulator and microelement treatments on total chlorophyll and total carbohydrates in leaves of peace lily during two successive seasons (2016/2017 and 2017/2018).

\begin{tabular}{|c|c|c|c|c|}
\hline \multirow{2}{*}{ Treatments } & \multicolumn{2}{|c|}{ Total chlorophyll (spad) } & \multicolumn{2}{|c|}{ Total carbohydrate (\%) } \\
\hline & $1^{\text {st }}$ season & $2^{\text {nd }}$ season & $1^{\text {st }}$ season & $2^{\text {nd }}$ season \\
\hline & \multicolumn{4}{|c|}{ Effect of growth regulators } \\
\hline Tap water & 2.40 & 1.88 & 21.55 & 20.45 \\
\hline $\mathrm{GA}_{3} 100 \mathrm{ppm}$ & 2.77 & 2.71 & 23.13 & 23.03 \\
\hline $\mathrm{GA}_{3} 200 \mathrm{ppm}$ & 2.75 & 2.70 & 23.23 & 22.05 \\
\hline Kin. 100 ppm & 3.06 & 3.07 & 24.50 & 24.05 \\
\hline Kin. 200 ppm & 3.19 & 3.08 & 24.06 & 23.03 \\
\hline \multirow[t]{2}{*}{ LSD at 0.05 level } & 0.17 & 1.20 & 0.67 & 0.52 \\
\hline & \multicolumn{4}{|c|}{ Effect of microelements } \\
\hline Tap water & 2.70 & 2.40 & 21.90 & 20.96 \\
\hline $1 \mathrm{~g} / \mathrm{l}$ & 2.83 & 2.74 & 22.92 & 22.26 \\
\hline $2 \mathrm{~g} / \mathrm{l}$ & 2.91 & 2.72 & 23.90 & 23.62 \\
\hline $3 \mathrm{~g} / \mathrm{l}$ & 2.90 & 3.88 & 24.44 & 23.24 \\
\hline LSD at 0.05 level & 0.10 & 0.48 & 0.69 & 0.55 \\
\hline
\end{tabular}

Hippeastrum vittatum and Sardoei (2014b) on peace lily, who found that sprayed plant with $\mathrm{GA}_{3}$ or BA gave higher concentrations of total chlorophyll and total carbohydrates in leaves than in unsprayed plants

\section{Effect of microelements:}

The obtained results in Table (7) indicate that spraying peace lily with different microelements reflected significant effects on total chlorophyll and total carbohydrates in leaves more than in unsprayed plants in both seasons.

Total chlorophyll and total carbohydrates were significantly increased with plants sprayed with $3 \mathrm{~g} / \mathrm{l}$ microelements without significant differences with 2 g/l microelements regarding total carbohydrates in both seasons and with 2 or $1 \mathrm{~g} / \mathrm{l}$ microelements concerning total chlorophyll in the $1^{\text {st }}$ season.

The increases in total chlorophyll in leaves were 7.77 and $13.33 \%$, total carbohydrates were 9.13 and $12.69 \%$ for plants sprayed with microelements at $2 \mathrm{~g} / \mathrm{l}$ and 7.40 and $61.66 \%$ for total chlorophyll and 11.59 and $10.87 \%$ for total carbohydrates with plants sprayed with Kin at $200 \mathrm{ppm}$ over unsprayed plants in the $1^{\text {st }}$ and $2^{\text {nd }}$ seasons, respectively.

These results here are in harmony with those revealed by Ahmad et al. (2010), who found that leaf chlorophyll contents were significantly increased in rose cultivars in response to foliar application of B (0.5\%), $\mathrm{Zn}(1.5 \%)$ and Fe (1.0\%), applied either alone or in different combinations when compared with unsprayed plants.

\section{Effect of the interaction between growth regulators and microelements:}

Data presented in Table (8) show that the interaction between growth regulators and microelements had significant effects on total chlorophyll and total carbohydrates in leaves than in unsprayed plants in both seasons.

The interaction between spraying plants with Kin at 100 ppm and 3 g/l microelements was the best interaction treatments for enhancing the concentration of total chlorophyll and total carbohydrates in leaves 
Table 8. Effect of the interaction between foliar spray applications with some growth regulator and microelement treatments on total chlorophyll and total carbohydrates in leaves of peace lily during two successive seasons (2016/2017 and 2017/2018).

\begin{tabular}{|c|c|c|c|c|c|}
\hline \multicolumn{2}{|c|}{ Treatments } & \multicolumn{2}{|c|}{ Total chlorophyll (spad) } & \multicolumn{2}{|c|}{ Total carbohydrate (\%) } \\
\hline $\begin{array}{l}\text { Growth } \\
\text { regulators }\end{array}$ & Microelements & $1^{\text {st }}$ season & $2^{\text {nd }}$ season & $1^{\text {st }}$ season & $2^{\text {nd }}$ season \\
\hline \multirow[t]{4}{*}{ Tap water } & Tap water & 2.10 & 1.75 & 20.50 & 18.70 \\
\hline & $1 \mathrm{~g} / \mathrm{l}$ & 2.40 & 1.80 & 21.30 & 20.50 \\
\hline & $2 \mathrm{~g} / \mathrm{l}$ & 2.45 & 1.85 & 22.10 & 21.10 \\
\hline & $3 \mathrm{~g} / \mathbf{l}$ & 2.66 & 2.10 & 22.30 & 21.50 \\
\hline \multicolumn{2}{|c|}{$\mathrm{GA}_{3} 100 \mathrm{ppm}$ Tap water } & 2.70 & 2.20 & 22.10 & 21.60 \\
\hline & $1 \mathrm{~g} / 1$ & 2.79 & 3.35 & 23.10 & 22.50 \\
\hline & $2 \mathrm{~g} / 1$ & 2.90 & 2.70 & 23.20 & 24.70 \\
\hline & $3 \mathrm{~g} / 1$ & 2.70 & 2.60 & 24.10 & 23.30 \\
\hline \multicolumn{2}{|c|}{$\mathrm{GA}_{3} 200 \mathrm{ppm}$ Tap water } & 2.68 & 2.50 & 21.50 & 20.30 \\
\hline & $1 \mathrm{~g} / \mathrm{l}$ & 2.75 & 2.65 & 22.50 & 21.60 \\
\hline & $2 \mathrm{~g} / \mathrm{l}$ & 2.80 & 2.75 & 24.30 & 23.50 \\
\hline & $3 \mathrm{~g} / 1$ & 2.75 & 2.90 & 24.60 & 22.80 \\
\hline \multicolumn{2}{|c|}{ Kin. 100 ppm Tap water } & 2.90 & 2.85 & 22.60 & 22.50 \\
\hline & $1 \mathrm{~g} / 1$ & 3.00 & 2.90 & 24.10 & 24.40 \\
\hline & $2 \mathrm{~g} / 1$ & 3.10 & 3.00 & 25.60 & 25.20 \\
\hline & $3 \mathrm{~g} / 1$ & 3.25 & 3.53 & 25.70 & 24.10 \\
\hline \multicolumn{2}{|c|}{ Kin. 200 ppm Tap water } & 3.10 & 2.85 & 22.80 & 21.70 \\
\hline & $1 \mathrm{~g} / \mathrm{l}$ & 3.20 & 3.00 & 23.60 & 22.30 \\
\hline & $2 \mathrm{~g} / 1$ & 3.30 & 3.30 & 24.30 & 23.60 \\
\hline & $3 \mathrm{~g} / 1$ & 3.15 & 3.15 & 25.50 & 24.50 \\
\hline \multicolumn{2}{|c|}{ LSD at 0.05 level } & 0.22 & 1.08 & 1.55 & 1.24 \\
\hline
\end{tabular}

in both seasons, followed by Kin at $200 \mathrm{ppm}$ and $2 \mathrm{~g} / \mathrm{l}$ microelements regarding total chlorophyll in both seasons or with Kin at $100 \mathrm{ppm}$ and $2 \mathrm{~g} / \mathrm{l}$ microelements for total carbohydrates in leaves in both seasons.

The relative increases in total chlorophyll in leaves were 54.76 and $101.71 \%$, whereas total carbohydrates were 25.36 and $28.87 \%$ for the interaction between Kin at $100 \mathrm{ppm}$ and $3 \mathrm{~g} / \mathrm{l}$ microelements over unsprayed plants in the $1^{\text {st }}$ and $2^{\text {nd }}$ seasons, respectively.

Finally, the best interaction treatment for increasing growth, flowering and biochemical constituents was obtained with Kin at 100 ppm and 2 g/l microelements.

\section{REFERENCES}

Abou-El-Ghait, Eman M.; Gomaa, A.O.; Youssef, A.S.M. and EL-Nemr, A.M. (2018). Effect of kinetin and $\mathrm{GA}_{3}$ treatments on growth and flowering of Dendranthema grandiflorium cv. Art Queen plants. Middle East J. Agric. Res., 7(3):801-815.

Ahmad, I.; Khan, M.A.; Qasim, M.; Ahmad, R. and Randhawa, M.A. (2010). Growth, yield and quality of Rosa hybrida L. as 
Influenced by various micronutrients. Pak. J. Agric. Sci., 47:5-12.

Amran, K.A.A. (2013). Physiological Studies on Pelargonium graveolens L. Plant. Ph.D. Thesis, Fac. Agric., Moshtohor, Benha Univ., Egypt.

Amuamuha, L.; Pirzad, A. and Hadi, H. (2012). Effect of varying concentrations and time of Nanoiron foliar application on the yield and essential oil of pot marigold. Intl. Res. J. Appl. Basic. Sci., 3(10):2085-2090.

A.O.A.C. (1980). Official Methods of Analysis, The Association of Official Agricultural Chemists, $11^{\text {th }}$ Ed. P. O. Box 540, Washington D. C., USA.

Barciszewski J.; Siborska, G.; Clark, B.F.C. and Rattan, S.I.S. (2000). Cytokinin formation by oxidative metabolism. J. Plant Physiology, 158:587-588.

Bashir, M.A.; Waqas, A.; Ahmad, K.S.; Shehzad, M.A.; Sarwar, M.; Salman, A.M.; Ghani, I.; Shafi, J. and Iqaba, M. (2013). Efficacy of foliar application of micro nutrients on growth and flowering of Gerbera jamesonii L. IJAVMS, 7(3):108-116.

Cheema, G.S. and Sharma D.P. (1982). In vitro propagation of apple rootstocks. Int. Hort. Congr XXI. Hamburg, German Federal Republic, Int. Soc. Hort. Sci., 1: 1035 (Chem. Abst., 52:7692).

Chopde, N.; Nehare, N.; Maske, S.R.; Lokhande, S. and Bhut, P.N. (2015). Effect of foliar application of zinc and iron on growth, yield and quality of gladiolus. Plant Archives, 15(1):417-419.

Dashora, R.M.; Verma, P. and Dashora, L.K. (2004). Effect of growth retardants and micronutrients on growth and yield of African marigold (Tagetes erecta L.) cv. Pusa Basanti. Sci. Hort., 9: 213-218.

Davies, P.J. (1995). The Plant Hormones: Their Nature, Occurrence, and Functions. Kluwer Academic Publishers, Dordrecht, the Netherlands, pp. 1-15.
Devlin, M. and Witham, H. (1983). Plant Physiology, $4^{\text {th }}$ Ed. Publishers Willard, Grant Press, Boston, USA,

Dubois, M.; Gilles, K.A.; Hamillon, J.; Rebers, P.A. and Smith, F. (1956). Colorimeteric methods for determination of sugars and related substances. Anal. Chem., 28:350-356.

El-Malt, A.A.T.; El-Maadawy, E.E.; ElKhateeb, M.A. and El-Sadak, Z.H. (2006). Physiological studies on Hippeastrum vittatum L. plants, 2- Effect of NPK, CCC and BA on growth, bulblet production and flowering. Egypt. J. of Appl. Sci., (6B):724-742.

Fahad, S.; Masood Ahmad, Kh.; Akbar Anjum, M. and Hussain, S. (2014). The effect of micronutrients (B, $\mathrm{Zn}$ and $\mathrm{Fe}$ ) foliar application on the growth, flowering and corm production of gladiolus (Gladiolus grandiflorus L.) in calcareous soils. J. Agr. Sci. Tech., 16:1671-1682.

Helal, H.M. and Sauerbesk, D. (1986). Entwicklung und Aktivitat des Wurzelsysteme in Abhangigheit von der Bodendichte. Landw Forsch., 20:381388

Henny, R.J.; Norman, D.J. and Chen, J. (2004). Progress in ornamental aroid breeding research. Ann. of the Missouri Botanical Garden, 91:465-473.

Ibrahim, S.M.M.; Taha, L.S. and Farahat, M.M. (2010). Vegetative growth and chemical constituents of croton plants as affected by foliar application of benzyladenine and gibberellic acid. J. Amer. Sci., 6(7):126-130.

Khalifa, R.K.M.; Shaaban, S.H.A. and Rawia, A. (2011). Effect of foliar application of zinc sulphate and boric acid on growth, yield and chemical constituents of Iris plants. Ozean J. Appli. Sci., 4(2):129-144.

Khosa, S.S.; Younis, A.; Rayit, A.; Yasmeen, S. and Riaz, A. (2011). Effect of foliar application of macro and micro nutrients on growth and flowering of 


\section{Naglaa F.S. Elbohy}

Gerbera jamesonii L. Amer. Euras. J. Agric. Environ. Sci., 11:736-757.

Lahijie, M.F. (2012). Application of micronutrients $\mathrm{FeSO}_{4}$ and $\mathrm{ZnSO}_{4}$ on the growth and development of gladiolus Variety “Oscar”. Int. J. Agric. Crop Sci., 4:718-720.

Misra, H.P. (2001). Response of chrysanthemum to zinc and boron on growth, yield and quality of flowers. Sci. Hort., 7:201-208.

Mohamed, Y.F.Y. (2017). Effect of some growth stimulants on growth, flowering and postharvest quality of aster (Symphyotrichum novi-belgii L.) cv. Purple Monarch. Middle East J. Agric. Res., 6(2):264-273.

Mohammadipour, R. (2012). Effect of Fe Fertilization by Soil or Foliar Application on Growth Traits of Spathiphyllum. M.Sc. Thesis, Islamic Azad University, Rasht Branch, Rasht, Iran. (In Persian)

Murthy, D.; Rao, K.M. and Upendra, A. (2006). Effect of organically bound micronutrients on growth and yield of rice. J. Eco-Friendlily Agric., 3:86-87

Pal, S.; Barad, A.V.; Singh, A.K.; Khadda, B.S. and Kumar, D. (2016). Effect of foliar application of $\mathrm{Fe}$ and $\mathrm{Zn}$ on growth, flowering and yield of gerbera (Gerbera jamesonii) under protected condition. Indian J .Agri. Sci., 86(3):394398.

Praveena, R.; Ghosh, G. and Singh, V. (2018). Effect of foliar spray of boron and different zinc levels on growth and yield of Kharif green gram (Vigna radiata). Int. J. Curr. Microbiol. App. Sci., 7(8):1422-1428.

Rahbarian, P.; Salehi, S.A. and Fallah, I. A. (2014). Stimulatory Effect of benzyladenine and gibberellic acid on growth and photosynthetic pigments of Spathiphyllum wallisii Regel plants. Inter. J. Adv. Bio. Biomedical Res., 2(1):230-237.

Sajedi N.A.; Ardakani, M.R.; Naderi, A.; Madani, H. and Mashhadi, A.B.M.
(2009). Response of maize to nutrients foliar application under water deficit stress conditions. Am. J. Agric. Biol. Sci., 4(3):242-248

Salisbury, F.B. and Ross, C.W. (1974). Plant Physiology. Publishing Inc. Belmont. California, $2^{\text {nd }}$ ed., $422 \mathrm{p}$.

Sardoei, A.S. (2014a). Evaluation chlorophyll contents assessment on Spathiphyllum wall Regel with plant growth regulators. Inter J Bio. Sci., 4(2):306-310.

Sardoei, A.S. (2014b). Plant growth regulators effects on the growth and photosynthetic pigments on three indoor ornamental plants. European J. Experimen. Bio., 4(2):311-318.

Snedecor, G.W. and Cochran, W.G. (1980). Statistical Methods. $7^{\text {th }}$ ed. Iowa State Univ., Press, Ames., Iowa, U.S.A., 507 p.

Soni, S.S. and Godara, A.K. (2015). Effect of foliar application of borax, $\mathrm{FeSO}_{4}$ and $\mathrm{MnSO}_{4}$ on vegetative growth and flower production in gerbera. Res. Environ. Life Sci. Rel. Sci., 8(4):581-584.

Wahba, H.E. and Ezz El-Din, A.A., (2002). Growth, yield and essential oil response of Chrysanthemum coronarium L. to plant spacing and foliar micro-elements. Egypt. J. Hort., 29(2):229-247.

Youssef, A.S.M. and Abd El-Aal, M.M.M. (2014). Effect of kinetin and mineral fertilization on growth, flowering, bulbs productivity, chemical composition and histological features of Hippeastrum vittatum plant. J. Plant Production, Mansoura Univ., 5 (3):357-381.

Youssef, A.S.M. and Ismaeil, F.H.M. (2009). Response of Clivia miniata plant to light intensity and kinetin treatments. Annals of Agric. Sc., Moshtohor, 47(1):149-164.

Youssef, A.S.M. and Mady, M.A. (2013). Influence of light intensity and benzyladenine on growth performance of Aspidistra elatior Blume plant. Res. J. Agric. Bio. Sci., 9(5):248-257. 


\title{
استجابة نبات الاسباثيفيلل للرش الورقى بيعض منظمات النمو والعناصر الصغرى
}

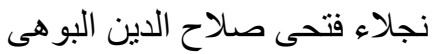 \\ قسم بحوث نباتات الزينة وتتسيق الحدائق، معهد بحوث البساتين، مركز البحوث البحث الزر اعية، الجيزة، مصر.
}

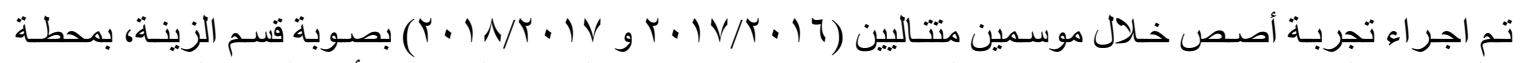

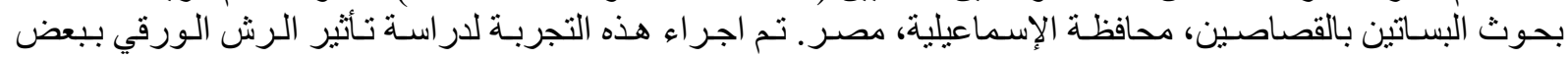

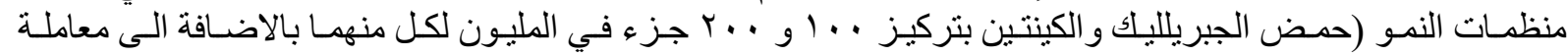

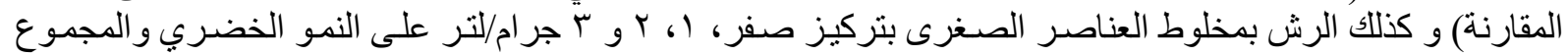
الجذري وجودة نبات الاسباتثفيللم.

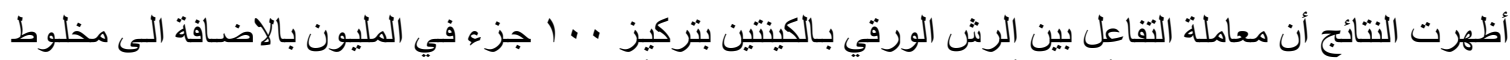

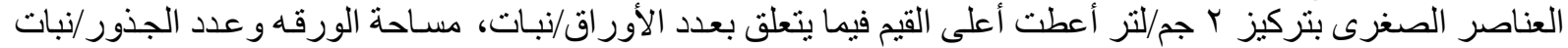

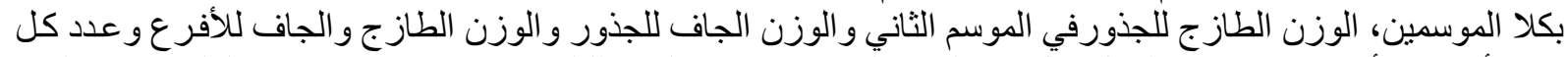

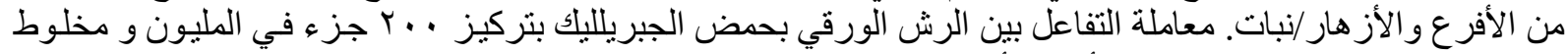

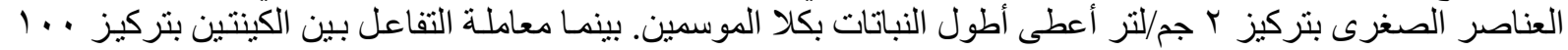

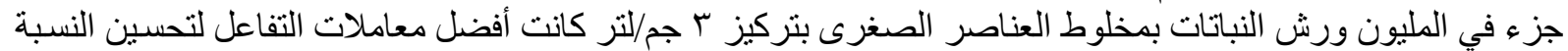

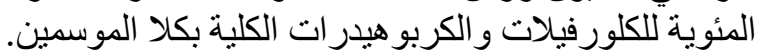

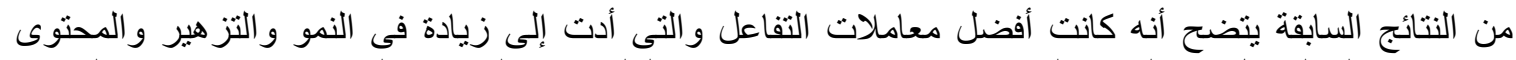

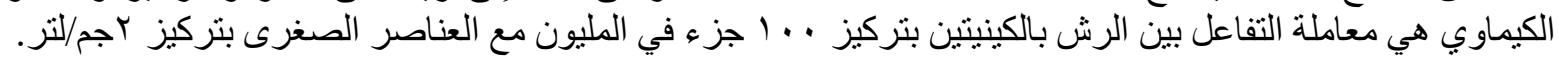




